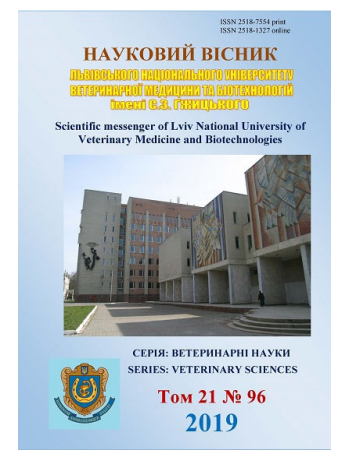

\author{
Науковий вісник Дьвівського національного університету \\ ветеринарної медицини та біотехнодогій імені С.3. Гжицького. \\ Серія: Ветеринарні науки \\ Scientific Messenger of Lviv National University \\ of Veterinary Medicine and Biotechnologies. \\ Series: Veterinary sciences
}

\title{
Monitoring of vector-borne diseases in the west part of Ukraine
}

\author{
V.A. Levytska, A.B. Mushinsky \\ State Agrarian and Engineering University in Podilya, Kamianets-Podilskyi, Ukraine
}

Article info

Received 01.10.2019 Received in revised form 30.10.2019

Accepted 31.10.2019

State Agrarian and Engineering University in Podilya, Shevchenko Str., 13, KamianetsPodilskyi, 32300, Ukraine. Tel.: +38-067-381-20-12 E-mail:Levytska28@gmail.com
Levytska, V.A., \& Mushinsky, A.B. (2019). Monitoring of vector-borne diseases in the west part of Ukraine. Scientific Messenger of Lviv National University of Veterinary Medicine and Biotechnologies. Series: Veterinary sciences, 21(96), 14-18. doi: 10.32718/nvlvet9603

During recent years, infectious and invasive animal diseases caused by viruses, bacteria, and protozoa and transmitted by ticks have been a new problem in medical and veterinary practice. Many of these diseases are zoonoses and lead to the disability and mortality of humans and animals. Ixodes ricinus and Dermacentor reticulatus are species of ticks that are commonly attack animals and humans in Europe. These ticks are spread throughout the EU and are involved in the transmission of a large number of vector-borne diseases. To date, relatively limited data on the circulation of tick-borne diseases and their transmission in western Ukraine are presented. The purpose of this study was to monitor the types of ixodid ticks, as well as to identify pathogens in ticks collected from the environment in urban parks and from dogs and cats. A total of 215 ticks (22 Ixodes ricinus and 193 Dermacentor reticulatus) collected in two regions of Lviv and IvanoFrankivsk were investigated. Pathogens, namely, Rikettsia spp., Candidatus Neoehrlichia mikurensis, Anaplasma phagocytophilum and Bartonella spp., were detected in $64.0 \%$ of the I. ricinus ticks. Overall, $18.2 \%$ of I. ricinus ticks were positive for Rikettsia spp., $54.5 \%$ for Candidatus Neoehrlichia mikurensis, 9.1\% for A. phagocytophilum and Bartonella spp. confirmed in $4.5 \%$ of the studied ticks. Mixed infestations were found in 5 samples of I. ricinus DNA, representing $22.7 \%$. In addition, $74.6 \%$ of D. reticulatus ticks were infested with these pathogens. Overall, $30.0 \%$ of D. reticulatus ticks were positive for Rikettsia spp., Candidatus Neoehrlichia mikurensis was confirmed in $54.9 \%$, A. phagocytophilum in 1.6\%, and Bartonella spp. in $6.2 \%$ of the studied ticks. Mixed infestations were found in 35 D. reticulatus DNA samples, representing $18.1 \%$. The prevalence of Rikettsia spp. in two regions of Lviv and Ivano-Frankivsk, among the studied ticks was $28.8 \%$, Bartonella spp. $-6.0 \%$, A. phagocytophilum - 2.3\%, Candidatus Neoehrlichia mikurensis $54.9 \%$. Our data indicate the presence of pathogens in urban populations of ticks of I. ricinus and D. reticulatus in west part of Ukraine. Monitoring of tick-borne diseases is an important tool in the prevention and control of infections transmitted to humans and animals.

Key words: Ixodes ricinus, Dermacentor reticulatus, Rickettsia spp., Candidatus Neoehrlichia mikurensis, Bartonella spp., Anaplasma phagocytophilum, Western Ukraine.

\section{Моніторинг трансмісивних захворювань, що передаються іксодовими кліщами, в західних областях України}

\author{
В.А. Левицька, А.Б. Мушинський
}

Подільський державний аграрно-технічний університет, Кам'янеиь-Подільський, Украӥна

\footnotetext{
Протягом останніх років інфекційні та інвазійні захворювання тварин, викликані вірусами, бактеріями і найпростішими, цчо передаються кліщами, є новою проблемою охорони здоров'я і ветеринарної практики. Багато таких захворювань є зоонозами $i$ призводять до інвалідності та смертності людей і тварин. Ixоdes ricinus i Dermacentor reticulatus - види кліщів, які часто нападають на тварин і людей у Європі. Ці кліщі поширені по всій території ЄС і беруть участь у передачі великої кількості трансмісивних захворювань. На сьогодні маємо досить обмежені дані щзодо ичиркуляиї іксодових кліщів $і$ захворювань, які вони переносять, у західній частині Украӥни. Метою даного дослідження був моніторинг видів іксодових кліщів, а також виявлення збудників кро-
} 
вопаразитарних захворювань у кліщах, зібраних з природного середовища в міських парках, а також на собаках $і$ котах. Всього було досліджено 215 кліщів (22 Ixоdes ricinus i 193 Dermacentor reticulatus), зібраних у двох областях: Львівській та ІваноФранківській. Збудники кровопаразитарних захворювань, а саме: Rikettsia spp., Candidatus Neoehrlichia mikurensis, Anaplasma phagocytophilum i Bartonella spp., були виявлені у 64,0\% досліджуваних клішів I. ricinиs. Загалом 18,2\% клішів I. riciпиs були позитивними щзодо Rikettsia spp., 54,5\% - Candidatus Neoehrlichia mikurensis, 9,1\% - A. phagocytophilum i Bartonella spp. nidmверджено y 4,5\% досліджених кліщув. Змішані інвазії виявили в 5 зразках ДНК I. ricinus, щуо становить 22,7\%. Крім того, 74,6\% кліщів D. reticulatus були інвазовані даними збудниками. Загалом 30,0\% кліщів D. reticulatus виявились позитивними на Rikettsia spp., Candidatus Neoehrlichia mikurensis було підтверджено у 54,9\%, A. phagocytophilum y 1,6\% i Bartonella spp. y 6,2\% досліджених кліщів. Змішані інвазї виявили в 35 зразках ДНК D. reticulatus, шуо становить 18,1\%. Виявлено, щчо поширеність Rikettsia spp. у двох областях - Львівській та Івано-Франківській, серед досліджуваних клішів становила 28,8\%, Вагтопеlla spр. - 6,0\%, A. phagocytophilum - 2,3\%, Candidatus Neoehrlichia mikurensis - 54,9\%. Наші дані свідчать про наявність збудників кровопаразитарних хвороб у міських популяціях кліщів I. ricinus та D. reticulatus в Україні. Моніторинг патогенів, щуо передаються кліщами, $\epsilon$ важливим інструментом у запобіганні інвазій та боротьбі з хворобами, щчо передаються людям і тваринам.

Ключові слова: Ixodes ricinus, Dermacentor reticulatus, Rickettsia spp., Candidatus Neoehrlichia mikurensis, Bartonella spp., Anaplasma phagocytophilum, Західна Україна.

\section{Вступ}

Протягом останніх років інфекційні та інвазійні захворювання тварин, викликані вірусами, бактеріями і найпростішими, що передаються кліщами, є новою проблемою охорони здоров'я і ветеринарної практики. Багато таких захворювань є зоонозами і призводять до інвалідності та смертності людей і тварин (Harrus \& Baneth, 2005). У країнах СС було проведено багато досліджень щодо вивчення поширення іксодових кліщів і патогенів, які вони можуть передавати (Bonnet et al., 2013; Reye et al., 2013; Elsheikha, 2016; Kybicova et al., 2017; Roczeń-Karczmarz et al., 2018; Duplan et al., 2018). Щодо України, то нещодавно почали з'являтись повідомлення стосовно поширеності даних патогенів на території нашої держави (Karbowiak et al., 2013; Didyk et al., 2016; Rogovskyy et al., 2017; Weiner et al., 2018).

Ixodes ricinus i Dermacentor reticulatus - види кліщів, які часто нападають на тварин і людей у Європі. Ці кліщі поширені по всій території Європи і беруть участь у передачі великої кількості трансмісивних захворювань.

Дані про поширеність патогенів серед кліщів Західної України майже відсутні. Були повідомлення про $3,6 \%$ і 5,2\% інфікованості A. phagocytophilum досліджених кліщів I. ricinus у східній Україні та Києві відповідно (Movila et al., 2009; Karbowiak et al., 2013; Hamel et al., 2013; Didyk et al., 2016; Rogovskyy et al., 2017). Ці дані можна порівняти з опублікованими даними з сусідніх країн, які повідомляють, що 2,0$2,7 \%$ I. ricinus були ПЛР-позитивними на A. phagocytophilum. Для порівняння: поширеність A. phagocytophilum серед досліджених I. ricinus становила 4,2\% у Білорусі, 2,9\% у Литві, 5,1-9,0\% у Молдові, 2,3-13,7\% у Польщі та 8,8\% у Pociï (Grzeszczuk et al., 2004; Movila et al., 2009; Olav et al., 2009; Reye et al., 2013; Livanova et al., 2018). У Словаччині ДНК $A$. phagocytophilum була виявлена в декількох міських i приміських районах 3 показниками інвазії від 1,4 до 5,5\% (Pangrácová et al., 2013). Показники поширеності A. phagocytophilum серед іксодових кліщів залежать від наявності резервуарних господарів, малих або середніх ссавців, а також птахів (Keesing et al., 2012). Останні дані свідчать, що лисиці та єнотові собаки можуть бути важливим резервуаром трансмісивних хвороб (Karbowiak et al., 2013; Härtwig et al., 2014), вони також можуть заноситись в міські парки 3 навколишніх лісів (Zagorodniuk, 2003).

Щодо дослідження патогенів, які можуть переносити кліщі Dermacentor spp., в Україні опублікувано дані Karbowiak et al. (2014). Досить високу поширеність A. phagocytophilum (25,4\%) виявлено у кліщів D. reticulatus 3 Чорнобильської зони відчуження. Кровопаразити роду Babesia також спостерігалися у 3,4\% досліджуваних кліщів. У цьому ж дослідженні 10,1\% кліщів D. reticulatus, зібраних в парковій зоні Чубинський Хутір Заказник, були позитивними на R. raoultii. Поширеність інвазії була нижчою, ніж у сусідніх країнах, наприклад 22-27\% у Словаччині (Spitalská et al., 2012), 57\% у Польщі (Chmielewski et al., 2009) або 22,6\% у Білорусі (Reye et al., 2013). Аналогічно вищі показники інвазованості Rickettsia spp i в Західній Європі, а саме 27\% кліщів були позитивними у Великобританії (Tijsse-Klasen et al., 2013), 23\% у Німеччині (Dautel et al., 2006), 14\% у Нідерландах (Nijhof et al., 2007). Такі розбіжності можна пояснити методами відбору зразків та різними молекулярними методиками дослідження, що використовуються для діагностики.

Candidatus Neoehrlichia mikurensis є трансмісивною зоонозною бактерією 3 сімейства Anaplasmataceae, яка нещодавно 3'явилась у Європі (Kawahara et al., 2004; Blaňarová et al., 2015). Це облігатний внутрішньоклітинний грамнегативний організм, що передається кліщами Ixodes у помірних районах північної півкулі (Schouls et al., 1999; Vichova et al., 2014; Derdakova et al., 2014). В Свропі Candidatus N. mikurensis було виявлено в личинках, німфах і дорослих кліщах I. ricinus у Німеччині та Швейцарії, поширенісь від 2,6\% до 6,4\% відповідно (Silaghi et al., 2012; Burri et al., 2014). У Словаччині Candidatus N. mikurensis було виявлено у 2,4\% німф та і 2,6\% дорослих особин I. ricinus.

Ще до недавнього часу даних щодо виявлення Bartonella spp. серед кліщів з України не було. Але нещодавнє дослідження продемонструвало, що 1,0 i 2,7\% досліджених дорослих кліщів D. reticulatus i I. ricinus відповідно були позитивними на Bartonella spp. 3 парків Києва. Іншими дослідженнями також виявлено наявність ДНК $B$. henselae в 11,8 і 0,5 - 2,9\% досліджених німф і дорослих I. ricinus в Німеччині, 
32,3 і 0\% в Португалії і 38,2 і 12,0\% у Франції відповідно (Dietrich et al., 2010).

\section{Матеріал і методи досліджень}

Дослідження проводилося в західній Україні протягом 2017-2019 років. Всього було зібрано 215 кліщів 3 природніх стацій, а також 3 тварин. Протягом весняного та осіннього періодів активності кліщів ї збирали на типових пішохідних маршрутах та у міських парках за допомогою білого фланелевого прапора $(1 \times 1$ м) з трави, чагарників та кущів (до 1,5 м у висоту). Зібраний матеріал зберігали в пластикових пробірках. Другу групу кліщів збирали з котів та собак у ветеринарних клініках міст Львова та ІваноФранківська. Паразитів видаляли з тварин пінцетом і поміщали в пробірку Еппендорфа. До подальших досліджень кліщів зберігали в 70\% етиловому спирті. Далі визначали стадію розвитку, рід і вид кожного кліща, використовуючи світлові мікроскопи і потім зберігали для подальших молекулярно-генетичних досліджень.

ДНК виділили з 215 іксодових кліщів. Кліщів промивали від етанолу і подрібнювали. Виділення ДНК проводили, використовуючи набір DNeasy Blood \& Tissue Kit (250) (QIAGEN, Німеччина), згідно 3 інструкціями виробника. Кліща подрібнювали скальпелем в пробірці, центрифугували, додавали 180 мкл буферного розчину (Т1) і 25 мкл протеїнази, змішували в вортексі, потім центрифугували і поміщали в термостат при $56^{\circ} \mathrm{C}$ протягом 1-3 годин. Зразки ДНК зберігали при $-20{ }^{\circ} \mathrm{C}$ до подальших аналізів.

\section{Полімеразна ланцюгова реакція (ПЛР).}

Реакції ПЛР проводили на наявність Anaplasma phagocytophilum, Rickettsia spp., Bartonella spp., Candidatus Neoehrlichia mikurensis. Ампліфікацію проводили з використанням термоциклера MyCycler (BioRad, США). Кожну реакцію ПЛР проводили в 25 мкл об'єму, що містить 5 мкл 5х суміші FIREPol (Solis BioDyne, Естонія), 1 мкл кожного праймера, 5 мкл ДНК (зразок) і 13 мкл стерильної води для PCR Master Mix. У кожній ПЛР як позитивний контроль використовували раніше виявлені зразки ДНК патогенів. Сте- рильну воду додавали в ПЛР-суміш замість зразка ДНК як негативного контролю.

Продукти ПЛР аналізували за допомогою електрофорезу в 1,5\% агарозному гелі, забарвленому GoodView Nucleic Acid Stain (Beijing SBS Genetech, Пекін, Китай), і візуалізували ультрафіолетовим світлом.

\section{Результати та їх обговорення}

Всього було зібрано 215 кліщів, серед них було ідентифіковано Ixodes ricinus - 22 (14 самок, 8 самців) та Dermacentor reticulatus - 193 (126 самок, 67 самців), зібраних з рослинності (34) і від кішок (19) та собак (162).

Серед досліджених кліщів I. ricinus збудники кровопаразитарних захворювань були виявлені у 64,0\% (14/22). Загалом 18,2\% (4/22) кліщів I. ricinus були позитивними до Rikettsia spp., 54,5\% (12/22) - до Candidatus Neoehrlichia mikurensis, 9,1\% (2/22) - до $A$. phagocytophilum i 4,5\% - до (1/22) Bartonella spp.. Змішані інвазії були виявлені у 5 досліджених зразках, що становить 22,7\%, одночасно були виявлені збудники Rikettsia spp. і A. phagocytophilum у кліщів.

Що стосується D. reticulatus, то у 74,6\% (144/193) досліджуваних кліщів було виявлено патогени, а саме 30,0\% (58/193) кліщів D. reticulatus, були позитивними до Rikettsia spp., Candidatus Neoehrlichia mikurensis було підтверджено у $54,9 \%$ (106/193), A. phagocytophilum - y 1,6\% (3/193) i Bartonella spp. у 6,2\% (12/193) досліджуваних кліщів. Коінвазування було виявлено у 35 кліщів, що становить 18,1\% від загальної кількості D. reticulatus. Тут виявляли і поєднання Rikettsia spp. та A. phagocytophilum, а також Rikettsia spp. i Bartonella spp. та A. phagocytophilum i Bartonella spp.

Усі збудники були виявлені як у кліщів, зібраних на природі, так і в знятих з тварин. Rickettsia spp. були присутні в 7 зразках від кліщів, зібраних на природі, та у 55, знятих з тварин, Bartonella spp. виявлені в 3 кліщів 3 природи і 10 кліщів від тварин, A. phagocytophilum - у 1 i 4, Candidatus Neoehrlichia mikurensis - y 10 і 120 відповідно, зібраних на природі та $з$ тварин (табл. 1).

\section{Таблиця 1}

Поширеність збудників трансмісивних хвороб серед дорослих кліщів I. ricinus i D. Reticulatus

\begin{tabular}{ccccccccc}
\hline \multirow{2}{*}{ Вид тварин/ Збудник } & \multicolumn{2}{c}{ Rickettsia spp. } & \multicolumn{2}{c}{ Bartonella spp. } & A.phagocytophilum & \multicolumn{2}{c}{ Candidatus Neoehrlichia mikurensis } \\
\cline { 2 - 9 } & DR & IR & DR & IR & DR & IR & DR & IR \\
\hline Собаки, коти & $52 / 162$ & $3 / 19$ & $9 / 162$ & $1 / 19$ & $3 / 162$ & $1 / 19$ & $109 / 162$ & $11 / 19$ \\
Вегетація & $6 / 31$ & $1 / 3$ & $3 / 31$ & $0 / 3$ & $0 / 31$ & $1 / 3$ & $9 / 31$ & $1 / 3$ \\
Всього & $58 / 193$ & $4 / 22$ & $12 / 193$ & $1 / 22$ & $3 / 193$ & $2 / 22$ & $118 / 193$ & $12 / 22$ \\
\hline
\end{tabular}

\section{Висновки}

Отже, підсумовуючи всі отримані дані, виявлено, що поширеність Rikettsia spp. у двох областях: Львівській та Івано-Франківській серед досліджуваних кліщів становила 28,8\%, Bartonella spp. - 6,0\%,

$$
\begin{aligned}
& \text { A. phagocytophilum - 2,3\%, Candidatus Neoehrlichia } \\
& \text { mikurensis-54,9\%. }
\end{aligned}
$$

Наші дані свідчать про наявність збудників кровопаразитарних хвороб у міських популяціях кліщів I. ricinus та D. reticulatus в Україні. Моніторинг патогенів, що передаються кліщами, є важливим інстру- 
ментом у запобіганні інвазій та боротьбі з інвазійними хворобами, що передаються людям і тваринам.

Планується проведення подальших досліджень кліщів для визначення інших патогенів.

\section{References}

Harrus, S., \& Baneth, G. (2005). Drivers for the emergence and re-emergence of vector-borne protozoal and bacterial diseases. International journal for parasitology, 35(1112), 1309-1318. doi: 10.1016/j.ijpara.2005.06.005.

Bonnet, S., de la Fuente, J., Nicollet, P., Liu, X., Madani, N., Blanchard, B., Maingourd, G., Alongi, A., Torina, A., Fernández de Mera, I.G., Vicente, J., George, J.C., Vayssier-Taussat, M., \& Joncour, G. (2013). Prevalence of tick-borne pathogens in adult Dermacentor spp. ticks from nine collection sites in France. VectorBorne Zoonotic Dis, 13(4), 226-236. doi: 10.1089/vbz.2011.0933.

Roczeń-Karczmarz, M., Dudko, P., DemkowskaKutrzepa, M., Meisner, M., Studzińska, M., Junkuszew, A., Sopińska, A., \& Tomczuk, K. (2018). Comparison of the occurrence of tick-borne diseases in ticks collected from vegetation and animals in the same area. Medycyna Weterynaryjna, 74, 484-488. doi: $10.21521 / \mathrm{mw} .6107$.

Duplan, F., Davies, S., Filler, S., Abdullah, S., Keyte, S., Newbury, H., R Helps, C., Wall R., \& Tasker, S. (2018). Anaplasma phagocytophilum, Bartonella spp., haemoplasma species and Hepatozoon spp. in ticks infesting cats: A large-scale survey. Parasites \& Vectors. 11(1), 201. doi: 10.1186/s13071-018-2789-5

Elsheikha, H. (2016). Tick-borne diseases in dogs. The Veterinary Nurse, 7. doi: 10.12968/vetn.2016.7.8.440.

Reye, A., Stegniy, V., P Mishaeva, N., Velhin, S., Hübschen, J., Ignatyev, G., \& Muller, C. (2013). Prevalence of Tick-Borne Pathogens in Ixodes ricinus and Dermacentor reticulatus Ticks from Different Geographical Locations in Belarus. PloS one, 8, e54476. doi: 10.1371/journal.pone.0054476.

Kybicova, K., Baštová, K., \&Malý, M. (2017). Detection of Borrelia burgdorferi sensu lato and Anaplasma phagocytophilum in questing ticks Ixodes ricinus from the Czech Republic. Ticks and Tick-borne Diseases, 8(4), 483-487. doi: 10.1016/j.ttbdis.2017.02.007.

Karbowiak, G., Víchová, B., Slivinska, K., Werszko, J., Didyk, Y., \& Pet'ko, B. (2013). The infection of Dermacentor reticulatus ticks with Babesia canis and Anaplasma phagocytophilum in Chernobyl exclusion zone. Annals of Parasitology, 59, 171.

Didyk, Y., Blaňarová, L., Pogrebnyak, S., Akimov, I., Pet'ko, B., \& Víchová, B. (2016). Emergence of tickborne pathogens (Borrelia burgdorferi sensu lato, Anaplasma phagocytophilum, Ricketsia raoultii and Babesia microti) in the Kyiv urban parks, Ukraine. Ticks and Tick-borne Diseases. 8(2), 219-225. doi: 10.1016/j.ttbdis.2016.10.002.

Rogovskyy, A., Batool, M., Gillis, D., Holman, P., Nebogatkin, I., Rogovska, Y., \& Rogovskyy, M. (2017). Diversity of Borrelia spirochetes and other zo- onotic agents in ticks from Kyiv, Ukraine. Ticks and Tick-borne Diseases. 9(2), 404-409. doi: 10.1016/j.ttbdis.2017.12.006.

Weiner, M., Żukiewicz-Sobczak, W., Tokarska-Rodak, M., Plewik, D., Pańczuk, A., Siłuch, M., Zagórski, J., Sobczak, P., Chmielewski, T., TylewskaWierzbanowska, S., Shkilna, M., Korda, M., Klishch, I., Andreychyn, M., \& Pavliuk, M. (2018). Prevalence of Borrelia Burgdorferi Sensu Lato in Ticks from the Ternopil Region in Ukraine. Journal of Veterinary Research, 62(3), 275-280. doi: 10.2478/jvetres-20180039 .

Movila, A., Rolain, J.M., Podavalenko, A., Toderas, I., Tkachenco, L., Naglov, V., \& Raoult, D. (2009). Detection of spotted fever group rickettsiae and family Anaplasmataceae in Ixodes ricinus ticks from Republic of Moldova and Eastern Ukraine. Clin. Microbiol. Infect, 15(2), 32-33. doi: 10.1111/j.14690691.2008.02152.x.

Hamel, D., Silaghi, C., Zapadynska, S., Kudrin, A., \& Pfister, K. (2013). Vector-borne pathogens in ticks and EDTA-blood samples collected from clientowned dogs, Kiev, Ukraine. Ticks Tick Borne Dis, 4(1-2), 152-155. doi: 10.1016/j.ttbdis.2012.08.005.

Grzeszczuk, A., Ziarko, S., Prokopowicz, D., \& Radziwon, P.M. (2004). Zakazenie z ubrów z Puszczy Białowieskiej bakteriami Anaplasma phagocytophilum. Med. Wet., 60, 600-601 (in Polish).

Koci, J., Movila, A., Taragelova, V. et al. (2007). First detection of Anaplasma phagocytophilum and its coinfections with Borrelia burgdorferi sensu lato in Ixodes ricinus ticks (Acari: Ixodidae) from Republic of Moldova. Exp Appl Acarol, 41, 147-152.

Olav, R., Paulauskas, A., \& Radzijevskaja, J. (2009). Prevalence of Borrelia burgdorferi sensu lato and Anaplasma phagocytophilum in questing Ixodes ricinus ticks in relation to the density of wild cervids. Acta Veterinaria Scandinavica, 51, 47. doi: 10.1186/17510147-51-47.

Livanova, N., Fomenko, N., Akimov, I., Ivanov, M., Tikunova, N., Armstrong, R., \& Konyaev, S. (2018). Dog survey in Russian veterinary hospitals: Tick identification and molecular detection of tick-borne pathogens. Parasites \& Vectors. 11(1). doi: 10.1186/s13071-018-3161-5.

Pangrácová, L., Derdáková, M., Pekárik, L., Hviscová, I., Víchová, B., Stanko, M., Hlavatá, H., \& Pet'ko, B. (2013). Ixodes ricinus abundance and its infection with the tick-borne pathogens in urban and suburban areas of Eastern Slovakia. Parasit. Vectors, 6, 238246.

Keesing, F., Hersh, M.H., Tibbetts, M., Mc Henry, D.J., Duerr, S., Brunner, J., Killilea, M., Lo Giudice, K., Schmidt, K.A., \& Ostfeld, R.S. (2012). Reservoir competence of vertebrate hosts for Anaplasma phagocytophilum. Emerg. Infect. Dis, 18, 2013-2016.

Härtwig, V., von Loewenich, F.D., Schulze, C., Straubinger, R.K., Daugschies, A., \& Dyachenko, V. (2014). Detection of Anaplasma phagocytophilum in red foxes (Vulpes vulpes) and raccoon dogs (Nyctereutes pro- 
cyonoides) from Brandenburg, Germany. Ticks Tick Borne Dis, 5(3), 277-280.

Zagorodniuk, I.V. (2003). Wild mammal fauna of the Kyiv city and its vicinities, and trends in its urbanization. Vestnik zoologii, 37(6), 29-38.

Spitalská, E., Stefanidesová, K., Kocianová, E., \& Boldis, V. (2012). Rickettsia slovaca and Rickettsia raoultii in Dermacentor marginatus and Dermacentor reticulatus ticks from Slovak Republic. Experimental \& applied acarology, 57, 189-197. doi: 10.1007/s10493-0129539-8.

Chmielewski, T., Podsiadly, E., Karbowiak, G., \& Tylewska-Wierzbanowska, S. (2009). Rickettsia spp. in ticks, Poland. Emerg Infect Dis., 15(3), 486-488. doi: 10.3201/eid1503.080711.

Tijsse-Klasen, E., Hansford, K.M., Jahfari, S., Phipps, P., Sprong, H., \& Medlock, J.M. (2013). Spotted fever group rickettsiae in Dermacentor reticulatus and Haemaphysalis punctata ticks in the UK. Parasit Vectors, 6, 212. doi: 10.1186/1756-3305-6-212.

Dautel, H., Dippel, C., Oehme, R., Hartelt, K., Frfr, V., \& Schenck, E. (2006). Evidence for an increased geographical distribution of Dermacentor reticulatus in Germany and detection of Rickettsia sp. RpA4. International journal of medical microbiology: IJMM, 296(40), 149-156. doi: 10.1016/j.ijmm.2006.01.013.

Nijhof, A.M., Bodaan, C., Postigo, M., Nieuwenhuijs, H., Opsteegh, M., Franssen, L., Jebbink, F., \& Jongejan, F. (2007). Ticks and associated pathogens collected from domestic animals in the Netherlands. Vector Borne Zoonotic Dis, 7(4), 585-595. doi: 10.1089/vbz.2007.0130.

Kawahara, M., Rikihisa, Y., Isogai, E., Takahashi, M., Misumi, H., Suto, C., Shibata, S., Zhang, C. \& Tsuji, M. (2004). Ultrastructure and phylogenetic analysis of 'Candidatus Neoehrlichia mikurensis' in the family Anaplasmataceae, isolated from wild rats and found in Ixodes ovatus ticks. Int J Syst Evol Microbiol 54, 1837-1843. doi: 10.1099/ijs.0.63260-0.

Blaňarová, L., Stanko, M., Miklisová, D., Víchová, B., Mošanský, L., Kraljik, J., Bona, M., Derdakova, M. (2015). Presence of Candidatus Neoehrlichia mikurensis and Babesia microti in rodents and two tick species (Ixodes ricinus and Ixodes trianguliceps) in Slovakia. Ticks and Tick-borne Diseases. 7(2), 319-326. doi: 10.1016/j.ttbdis.2015.11.008.
Schouls, L.M., Van De Pol, I., Rijpkema, S.G., \& Schot, C.S. (1999). Detection and identification of Ehrlichia Borrelia burgdorferi sensu lato, and Bartonella species in Dutch Ixodes ricinus ticks. J. Clin. Microbiol, 37(7), 2215-2222. https://www.ncbi.nlm.nih.gov/ pubmed/10364588.

Vichova, B., Majlathova, V., Novakova, M., Stanko, M., Hviscova, I., Pangracova, L., Chrudimsky, T., Curlik, J., \& Petko, B. (2014). Anaplasma infections in ticks and reservoir host from Slovakia. Infect. Genet. Evol., 22, 265-272. doi: 10.1016/j.meegid.2013.06.003.

Derdakova, M., Vaclav, R., Pangracova-Blanarova, L., Selyemova, D., Koci, J., Walder, G., \& Spitalska, E. (2014). Candidatus Neoehrlichia mikurensis and its co-circulation with Anaplasma phagocytophilum in Ixodes ricinus ticks across ecologically different habitats of Central Europe. Parasites Vectors 7, 160. https://parasitesandvectors.biomedcentral.com/articles /10.1186/1756-3305-7-160.

Silaghi, C., Woll, D., Hamel, D., Pfister, K., Mahling, M., \& Pfeffer, M. (2012). Babesia spp. and Anaplasma phagocytophilum in questing ticks, ticks parasitizing rodents and the parasitized rodents-analyzing the hostpathogen-vector interface in a metropolitan area. Parasites Vectors 191. https://parasitesandvectors.biomedcentral.com/articles /10.1186/1756-3305-5-191.

Jahfari, S., Fonville, M., Hengeveld, P., Reusken, C., Scholte, E.J., Takken, W., Heyman, P., Medlock, J., Heylen, D., Kleve, J., \& Sprong, H. (2012). Prevalence of Neoehrlichia mikurensis in ticks and rodents from North-west Europe. Parasites Vectors 5, 74. doi: 10.1186/1756-3305-5-74.

Burri, C., Schumann, O., Schumann, C., \& Gern, L. (2014). Are Apodemus spp. mice and Myodes glareolus reservoirs for Borrelia miyamotoi, Candidatus Neoehrlichia mikurensis, Rickettsia helvetica R. monacensis and Anaplasma phagocytophilum? Ticks Tick Borne Dis, 5(3), 245-251. doi: 10.1016/j.ttbdis.2013.11.007.

Dietrich, F., Schmidgen, T., Maggi, R., Richter, D., Matuschka, F., Vonthein, R., Breitschwerdt, E., \& Kempf, V. (2010). Prevalence of Bartonella henselae and Borrelia burgdorferi Sensu Lato DNA in Ixodes ricinus Ticks in Europe. Applied and environmental microbiology, 76, 1395-1398. doi: 10.1128/AEM.02788-09. 